\title{
STRUCTURE AND FREE VOLUME DISTRIBUTION IN Bi-Zn LIQUID ALLOYS
}

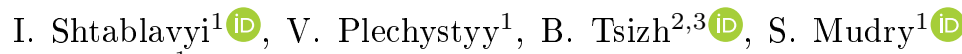 \\ 1 Ivan Franko National University of Lviv, \\ 8, Kyrylo \& Mefodiy St., Lviv, UA-79005, Ukraine, \\ ${ }^{2}$ Stepan Gzhytsky Lviv National University of Veterinary Medicine and Biotechnologies, \\ 50, Pekarska St., Lviv, UA-79010, Ukraine, \\ ${ }^{3}$ Kazimierz Wielki University, \\ J. K. Chodkiewicza 30, 85-064 Bydgoszcz, Poland
}

(Received 11 September 2020; in final form 09 November 2020; accepted 17 November 2020; published online 10 December 2020)

\begin{abstract}
Investigations of the structure and free volume distribution for near-eutectic $\mathrm{Bi}-\mathrm{Zn}$ alloys was carried out. X-ray diffraction and computer simulation methods for the structure studies of melts were used. As a result of the investigations, a considerable difference between the size of free volume within the first coordination sphere and its average values was established. It is assumed that the main reason for these differences is due to the peculiarities of the mechanism of dissolution of zinc in bismuth at its low concentrations, and the formation of chains of zinc atoms in the matrix of bismuth at higher zinc content in the melts.
\end{abstract}

Key words: liquid alloys, short range order structure, structure model, free volume.

DOI: https://doi.org/10.30970/jps.24.4601

\section{INTRODUCTION}

Investigations of the liquid state of matter are of interest not only from the fundamental point of view, but also from the practical point of view. Recently, metal melts have been studied not only to improve casting processes, but also in connection with the more exotic use of melts. In particular, low-melting alloys are used as a catalyst in the synthesis of carbon nanotubes, and they are also used in flexible electronics systems [1, 2]. Recently, liquid metals were proposed to be used as media for the synthesis of intermetallic compounds with unique properties [3]. In order to successfully use liquid metals and alloys, further in-depth study is needed.

Until now, the structure of metal melts has been studied mainly by interpreting changes in interatomic distances, coordination numbers and their partial values depending on external factors. However, the structure of disordered systems must be considered comprehensively, i.e. taking into account both the arrangement of atoms and the distribution of free volume. Such complex research became possible due to intensive development of computer methods of modeling of structure and properties the disordered systems.

Bismuth-zinc based alloys are promising for use as lead-free solders, directionally crystallized and dispersed materials. The $\mathrm{Bi}-\mathrm{Zn}$ system is characterized by the fact that it combines alloys with micro- and macro-inhomogeneities in the liquid state. Thus, at a zinc concentration of 8.1 at.\%, an eutectic reaction occurs; as a result, the crystalline alloy consists of bismuth based solid solution and zinc. At a higher zinc content at monotectic temperatures, there is a region of macroscopic phase immiscibility and this region extends from 37 to 99.3 atomic percent of zinc [4]. As is known, from the thermodynamic point of view, micro- and macro-immiscibility can be explained by higher values of the interaction energy between atoms of the same type and weaker interaction of different-type atoms. However, in many cases the entropy factor is not taken into account in the formation of immiscibile alloys.

Thus, so far there are no sufficiently substantiated explanations of the mechanism of formation of microand macroheterogeneous systems, not to mention the details of their atomic structure and physical properties. Given the fact, that heating such alloys much higher than the temperature of inhomogeneity leads to the transition of the systems with immiscible components of the alloy in a quasi-homogeneous state, a question arises about the atomic mechanism of such transformation, which must occur through intense diffusion processes. Similar phenomena will obviously be observed in the case of cooling the alloys and the transition to an inhomogeneous state. It is known that the diffusion processes in the liquid state can be explained by the lower density of the liquid compared to crystals and, consequently, the presence of a larger proportion of unoccupied volume.

Therefore, the study of the atomic structure of such alloys with the simultaneous analysis of the distribution of free volume can answer unresolved questions.

This work deals with a comprehensive study of the structure and distribution of the free volume of $\mathrm{Bi}-\mathrm{Zn}$ melts in the vicinity of the eutetic point. Due to the fact that $\mathrm{Bi}-\mathrm{Zn}$ alloys belong to systems with an immiscibility gap in the liquid state, the decisive role in the process of homogenization of such alloys is played by the distribution of free volume. In order to further analyze the distribution of free volume in the melts at different temperatures, the results of experimental studies and computer simulations were used.

The structure of the alloys of the Bi-Zn system was studied mainly in the range of concentrations that cover the immiscibile region in the liquid state [5-7]. In these works, it was shown that the main maxima of structure factors and pairwise correlation functions can be obtai- 
ned by simply adding the corresponding maxima for pure components. The results of thermodynamic studies show the presence of a significant maximum in the concentration dependence of the enthalpy and a minimum of entropy of the mixing of alloys in the vicinity of the immiscibile region [8-10]. On the other hand, in these works less attention was paid to the regions of eutectic and near-eutectic alloys of the $\mathrm{Bi}-\mathrm{Zn}$ system, which have a wide practical application. It should be noted that similar extremes also exist on experimental concentration dependences of other physical quantities $[11,12]$.

\section{INVESTIGATION METHODS}

Experimental investigations of the structure of melts was performed by the method of X-ray diffraction. The reconstruction of the atomic structure and the calculation of the free volume were carried out by computation methods.

In the experimental part of our work, prepared $\mathrm{Bi}-$ $\mathrm{Zn}$ (4-25 at.\% of $\mathrm{Zn}$ ) alloys were studied by X-ray diffractometer which was equipped with high-temperature chamber filled with pure helium in order to avoid the sample oxidation during the experiment. $\mathrm{Cu}-\mathrm{K}_{\alpha}$ radiation, monochromatized with $\mathrm{LiF}$ monocrystal, installed in initial beam and Bragg-Brentano focusing geometry were used. Scattered intensities were recorded with a different angular step, which was smaller within the region of the principal peak position and larger at rest values of scattering angles. Experimental results for intensities were corrected for polarization, absorption and incoherent scattering according to [13]. Upon this procedure they were normalized and then used for calculation of structure factors (SF), and pair correlation function (PCF) [14]. Main structure parameters obtained from these functions were analyzed.

The relative free volume within the first coordination sphere was calculated using the equation

$$
V_{\mathrm{f}}=1-\frac{3 V_{\mathrm{at}} \int_{0}^{R} \varrho(r) r^{2} d r}{R^{3}},
$$

where $V_{\text {at }}$ is the volume of the atom and $R$ is the boundary of the first coordination sphere.

Reconstruction of the atomic structure of $\mathrm{Bi}-\mathrm{Zn}$ melts was carried out by the reverse Monte Carlo (RMC) method [15, 16]. For the RMC simulation, a cubic cell that contained 5000 atoms was created. The dimensions of the model cell were selected according to the melt density at the experimental temperature. The minimum distances between atoms $r_{i j}$ were taken as the point of intersection of the left branch of the first maximum in an experimental PCF curve with the abscissa axis. As a result, the partial PCF and partial coordination numbers have been obtained.

The distribution of atoms in the simulated cell was used to calculate the free volume. To calculate the free volume, the atomic cell was divided into the Voronoi polyhedra. The volume of each polyhedron is the atomic volume at the same time. Therefore, the relative free volume per atom can be calculated as:

$$
\frac{V^{\mathrm{f}}}{V}=\frac{V_{\mathrm{p}}-V_{\mathrm{at}}}{V_{\mathrm{p}}},
$$

where $V_{p}$ is the volume of the Voronoi polyhedron for each atom, and $V_{\text {at }}$ is the volume of the atom.

The differential function of free volume distribution was calculated from:

$$
P=\frac{1}{N} \frac{d N_{i}}{d V}
$$

\section{RESULTS AND DISCUSSION}

A characteristic feature of structure factors for alloys of the $\mathrm{Bi}-\mathrm{Zn}$ system obtained at temperatures $5 \mathrm{~K}$ above the liquidus line (Fig. 1) is the presence of hump on the right side of its main maximum. This hump is usually explained by the preservation in the liquid state of a certain amount of covalent bonds in the form of shortterm localization of valence electrons in the bound state between pairs or groups of neighboring atoms. Another reason for the presence of the hump of the first maximum may be the influence of zinc microregions on the process of X-ray scattering, which leads to the additive superposition of the zinc intensity curve on the same bismuth curve. A similar conclusion was made in [5] which indicates a significant degree of segregation in the alloys of the $\mathrm{Bi}-\mathrm{Zn}$ system.

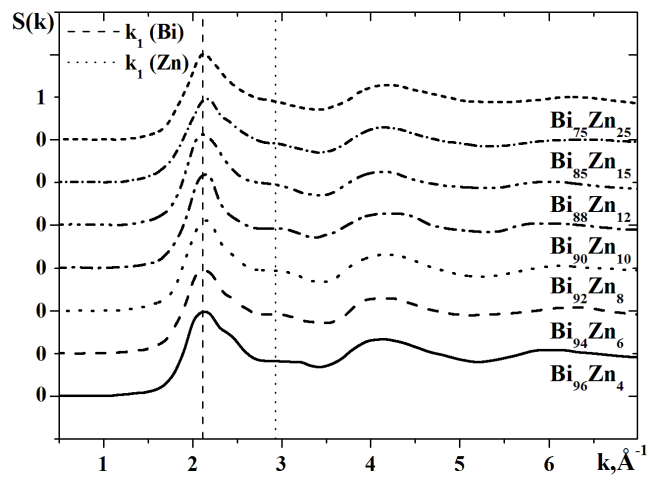

Fig. 1. Structure factors of near-eutectic alloys of the $\mathrm{Bi}-\mathrm{Zn}$ system at a temperature of $\mathrm{T}_{L}+5 \mathrm{~K}$

Segregation in the alloys of the $\mathrm{Bi}-\mathrm{Zn}$ system, or in other words, the formation of regions with a predominant neighborhood of the same type atoms, contributes to the temperature and concentration variations of the main structure parameters. As can be seen, on the concentration dependences of the height of the first maximum for different temperatures (Fig. 2) there is a maximum whose position is shifted to the region of higher concentrations compared to the eutectic point ( 8 at. $\% \mathrm{Zn})$. An increase in the height of the first maximum according to the hard 
sphere model [17] indicates an increase in the density of atomic packaging. This may indicate that zinc atoms will dissolve in the bismuth matrix, changing the topology of atomic ordering. It can be argued that neareutectic melts are characterized by a high density of atomic packaging, which decreases with deviations from the eutectic concentration. Moreover, this trend persists at higher temperatures.

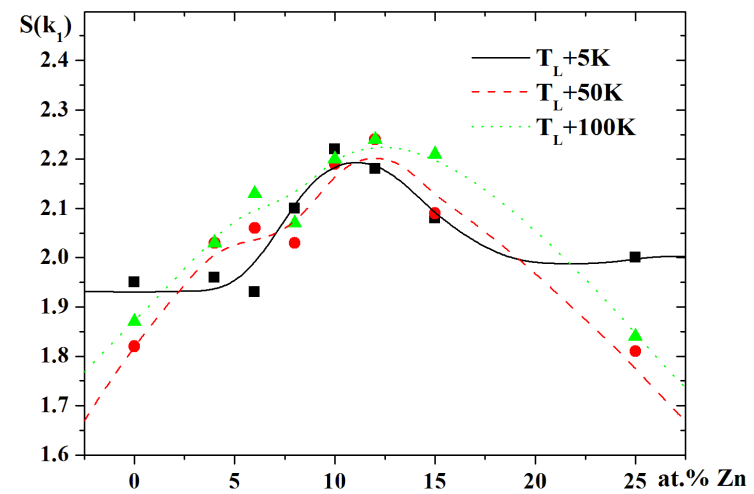

Fig. 2. Concentration dependences of the structure factor first maximum height for $\mathrm{Bi}_{100-x} \mathrm{Zn}_{x}$ alloys in the near-eutectic region of concentrations

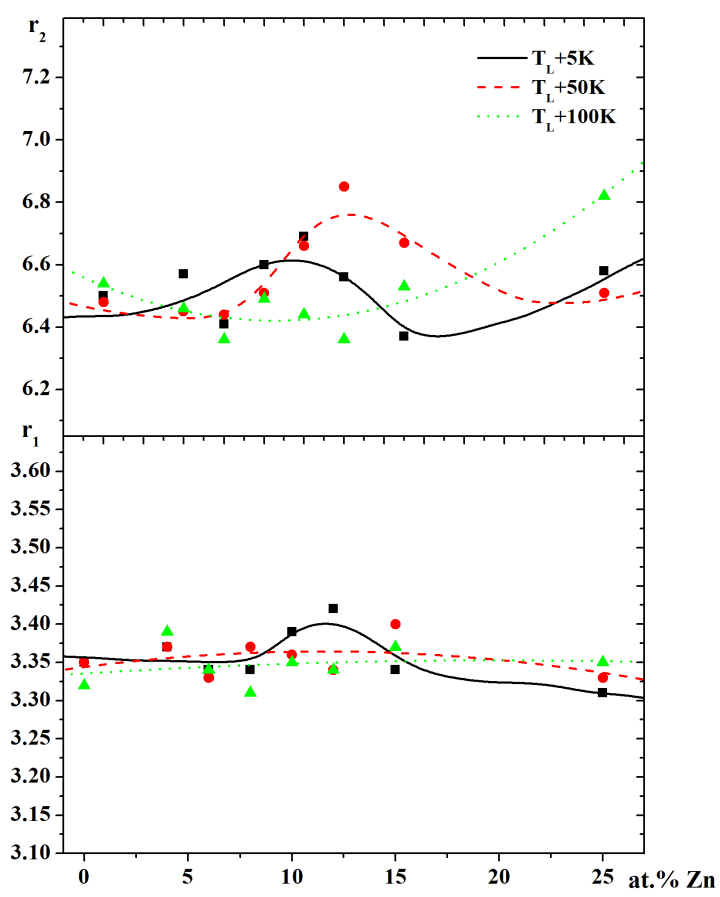

Fig. 3. Concentration dependences of the most probable interatomic distances in the first and second coordination spheres for alloys of the $\mathrm{Bi}_{100-x} \mathrm{Zn}_{x}$ system in the neareutectic region of concentrations

Similar extremes in the region of concentrations close to the eutectic point were also observed in the concentration dependences of the most probable interatomic distances in the first and second coordination spheres (Fig. 3). In particular, as we approach the eutectic concentration, the distances between the atoms increase. A small change in the distances between the atoms when the concentration of zinc in the alloy is less than 6 at.\% may indicate the dissolution of zinc in the bismuth based microregions. With a higher zinc content, it obviously forms clusters with its own type of structure.

The results of the model estimation of the concentration dependences of interatomic distances [18] indicate that the model of statistical distribution of atoms satisfactorily describes experimental results at the zinc content less than 6 at.\%, and further increase of the zinc concentration leads to a deviation of interatomic distances from the model values. This trend continues at higher temperatures.

The variations in interatomic distances described by us agree with the form of the $\mathrm{Bi}-\mathrm{Zn}$ phase diagram, which indicates a much higher solubility of zinc in bismuth than bismuth in zinc. Perhaps the decisive factor in this case is the large difference between the atomic radii of bismuth and zinc $\left(r_{1}^{\mathrm{Bi}}=1.6 \AA, r_{1}^{\mathrm{Zn}}=1.38 \AA\right)$, which indicates that the topological characteristics of the shortrange order structure are not conductive to the formation of a solution with a statistical distribution of atoms.

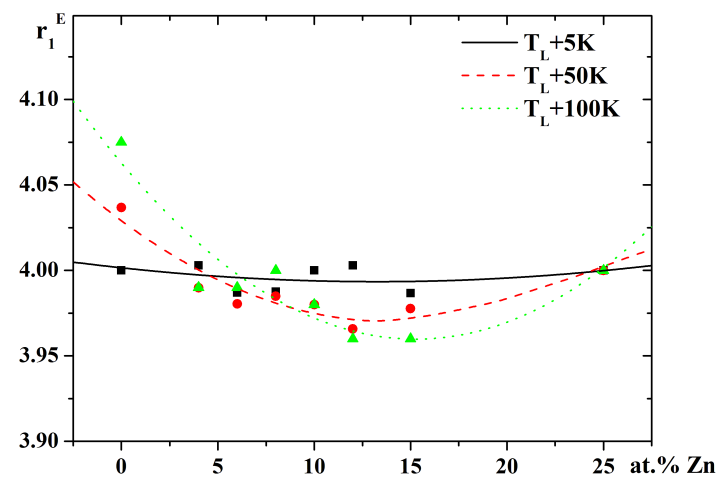

Fig. 4. Concentration dependences of the boundary of the first coordination sphere of the $\mathrm{Bi}_{100-x} \mathrm{Zn}_{x}$ system

In contrast to the growth of the most probable interatomic distances in the region of eutectic concentration, the boundary of the first coordination sphere shifts toward smaller distances as zinc content increases (Fig. 4), i.e. the size of the first coordination sphere decreases when approaching the eutectic concentration and increases with subsequent zinc addition. This is especially noticeable at higher temperatures.

The described changes in the main structure parameters indicate a rearrangement of the short-range order within the first coordination sphere, as a result, the addition of zinc to bismuth in the amount of up to 6 at\% leads to the formation of an atomic solution, and an increase in the zinc content causes the formation of a cluster solution based on pure components. 


\section{SHTABLAVYI, V. PLECHYSTYY, B. TSIZH, S. MUDRY}

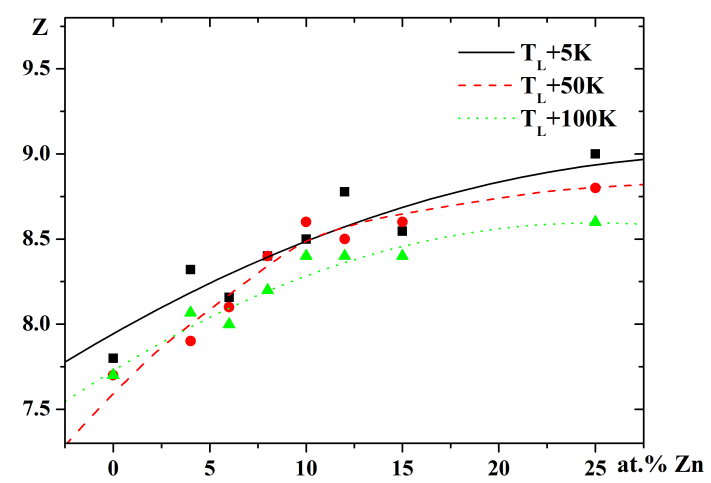

Fig. 5. Concentration dependences of the coordination number for alloys of the $\mathrm{Bi}_{100-x} \mathrm{Zn}_{x}$ system in the vicinity of the eutectic point

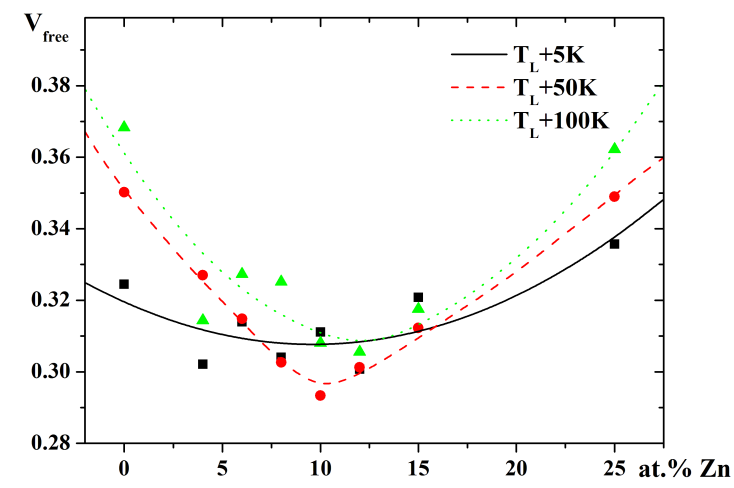

Fig. 6. Dependences of free volume within the first coordination sphere of $\mathrm{Bi}_{100-x} \mathrm{Zn}_{x}$ alloys on concentration

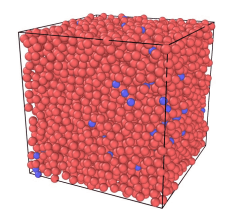

$\mathrm{Bi}_{96} \mathrm{Zn}_{4}$

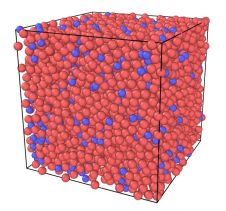

$\mathrm{Bi}_{88} \mathrm{Zn}_{12}$

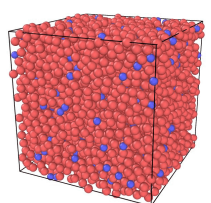

$\mathrm{Bi}_{92} \mathrm{Zn}_{8}$

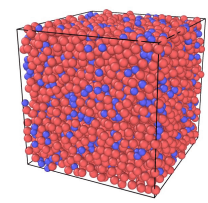

$\mathrm{Bi}_{75} \mathrm{Zn}_{25}$
Fig. 7. The configuration of atoms in the model cell of the melts of the $\mathrm{Bi}_{100-x} \mathrm{Zn}_{x}$ system for some concentrations of alloy components

An increase in the coordination number when zinc is added to bismuth (Fig. 5) may also indicate the dissolution of zinc in bismuth-based clusters. In this case, due to the smaller atomic radius of zinc, an increase in the coordination number may be accompanied by a decrease in the boundary of the first coordination sphere. On the other hand, the increase in zinc content in $\mathrm{Bi}_{100-x} \mathrm{Zn}_{x}$ alloys leads to the formation of clusters based on pure components, and due to the higher values of the coordination number of zinc compared to bismuth, the average coordination number of alloys increases.

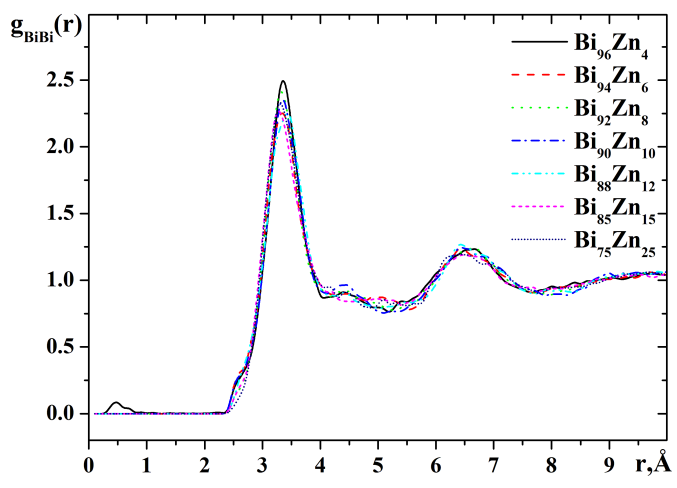

a)

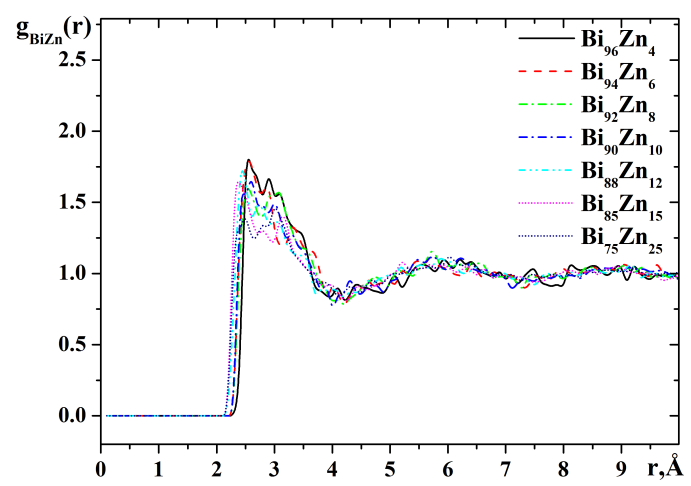

b)

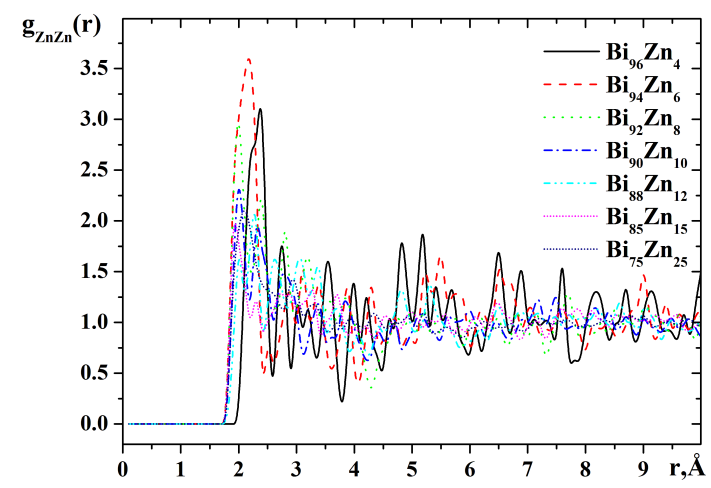

c)

Fig. 8. Partial pair correlation functions for $\mathrm{Bi}_{100-x} \mathrm{Zn}_{x}$ melts

The change in the main structure parameters leads to the variation in the free volume within the first coordination sphere (Fig. 6). As might be expected, a decrease in the boundary of the first coordination sphere and an increase in the coordination number lead to a decrease 
in the free volume by about $5 \%$ in the vicinity of the eutectic concentration. Outside the eutectic concentration, the fraction of the free volume in the first coordination sphere increases. A more detailed analysis of the distribution of the free volume is possible only by the results of computer modeling or reconstruction of the structure.

For alloys of the $\mathrm{Bi}_{100-x} \mathrm{Zn}_{x}$ system, the atomic structure was reconstructed by the RMC method. Atomic configurations obtained even for the case of low concentrations of zinc indicate a tendencv to associate

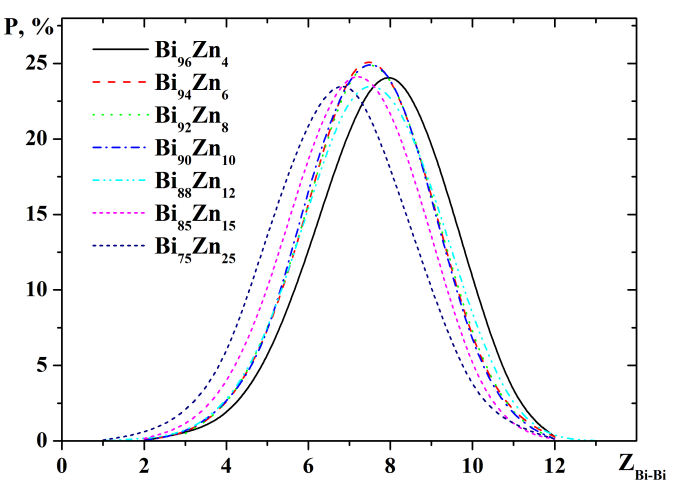

a)

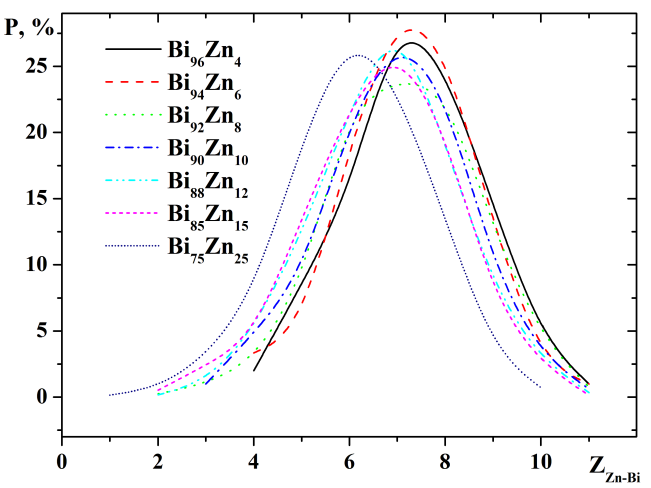

c) atoms of different types. With increasing concentration of zinc, this trend is more pronounced (Fig. 7). Another feature of the atomic structure of the investigated alloys is that the zinc atoms try to form asymmetrical clusters in the bismuth matrix, but form chains, whose length depends on the zinc content. This principle of the structure formation is obviously due to the significant difference in the atomic radii of bismuth and zinc, and the formation of zinc chains leads to an increase in the packing density and a decrease in the free volume.

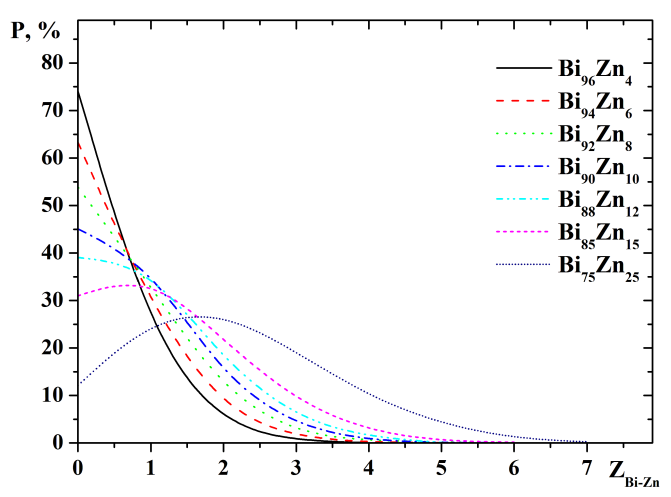

b)

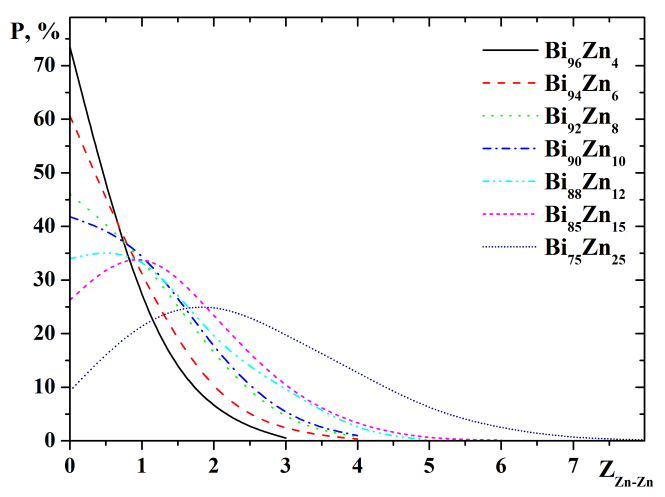

d)

Fig. 9. Distribution of partial coordination numbers of $\mathrm{Bi}_{100-x} \mathrm{Zn}_{x}$ system melts

Quantitatively, the correlation in the atomic arrangement can be described using partial pair correlation functions (Fig. 8) and coordination numbers (Figs. 9 and 10). The profile of partial pair correlation functions indicates a good correlation between the arrangement of bismuth atoms and pairs of bismuthzinc atoms. A weaker correlation is observed between zinc atoms in alloys with zinc content below eight atomic percent. In the case of a higher zinc content, the partial pair correlation functions $g_{\mathrm{ZnZn}}$ acquire a physical meaning. This feature indicates the formation of associated groups of zinc atoms when its content in the alloy is more than eight atomic percent. The described regularities are visually observed on the averaged distributions of atoms in the alloys obtained by the RMC method (Fig. 7).

The distribution of partial coordination numbers also indicates a greater degree of correlation between bismuth atoms and pairs of bismuth-zinc atoms compared to zinc atoms (Fig. 9). An increase in the zinc content leads to a decrease in the most probable values of the coordination numbers $Z_{\mathrm{Bi}-\mathrm{Bi}}$ and $Z_{\mathrm{Bi}-\mathrm{Zn}}$ and an increase in the coordination numbers $Z_{\mathrm{Zn}-\mathrm{Zn}}$. However, even with a zinc content of 25 atomic percent, the most probable value of the coordination number $Z_{\mathrm{Zn}-\mathrm{Zn}}$ is two, which indicates the formation of chains of zinc atoms in the bismuth matrix. Such changes lead to the formation of a denser structure due to the smaller radius of zinc atoms and, accordingly, to a decrease in the free volume. 


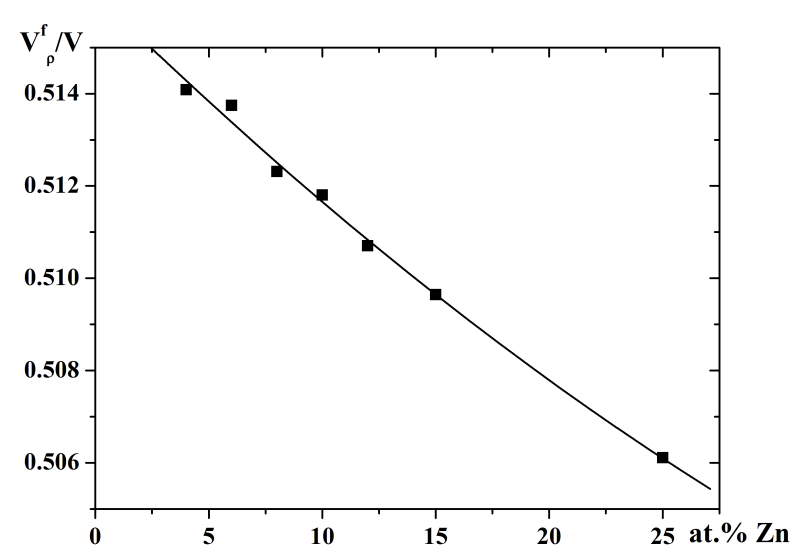

Fig. 10. Dependence of the free volume of $\mathrm{Bi}_{100-x} \mathrm{Zn}_{x}$ system melts on the concentration calculated from the density measurement results [19]
A change in the relative free volume can be estimated by the change in melt density [19]. As we can see (Fig. 10), the average relative free volume of the studied alloys decreases linearly, when zinc content increases. The value of the relative free volume, which is close to $50 \%$, agrees with the free volume, which can be calculated from the values of the packing density for bismuth $\left(\eta_{\mathrm{Bi}}=0.40\right)$ and zinc $\left(\eta_{\mathrm{Zn}}=0.46\right)$ according to the hard sphere model.

The differential distribution of the total and partial relative free volume (Fig. 11) for the studied alloys of the $\mathrm{Bi}-\mathrm{Zn}$ system indicates higher values of the free volume for zinc atoms compared to bismuth. An increase in the zinc content of the melt leads to a decrease in both the total and the partial most probable free volume (Fig. 12); in addition, the free volume of zinc atoms decreases faster compared to the free volume of bismuth atoms, which is almost unchanged. Therefore, it can be assumed that the decrease in the free volume is due to the decrease in the free volume of zinc atoms.

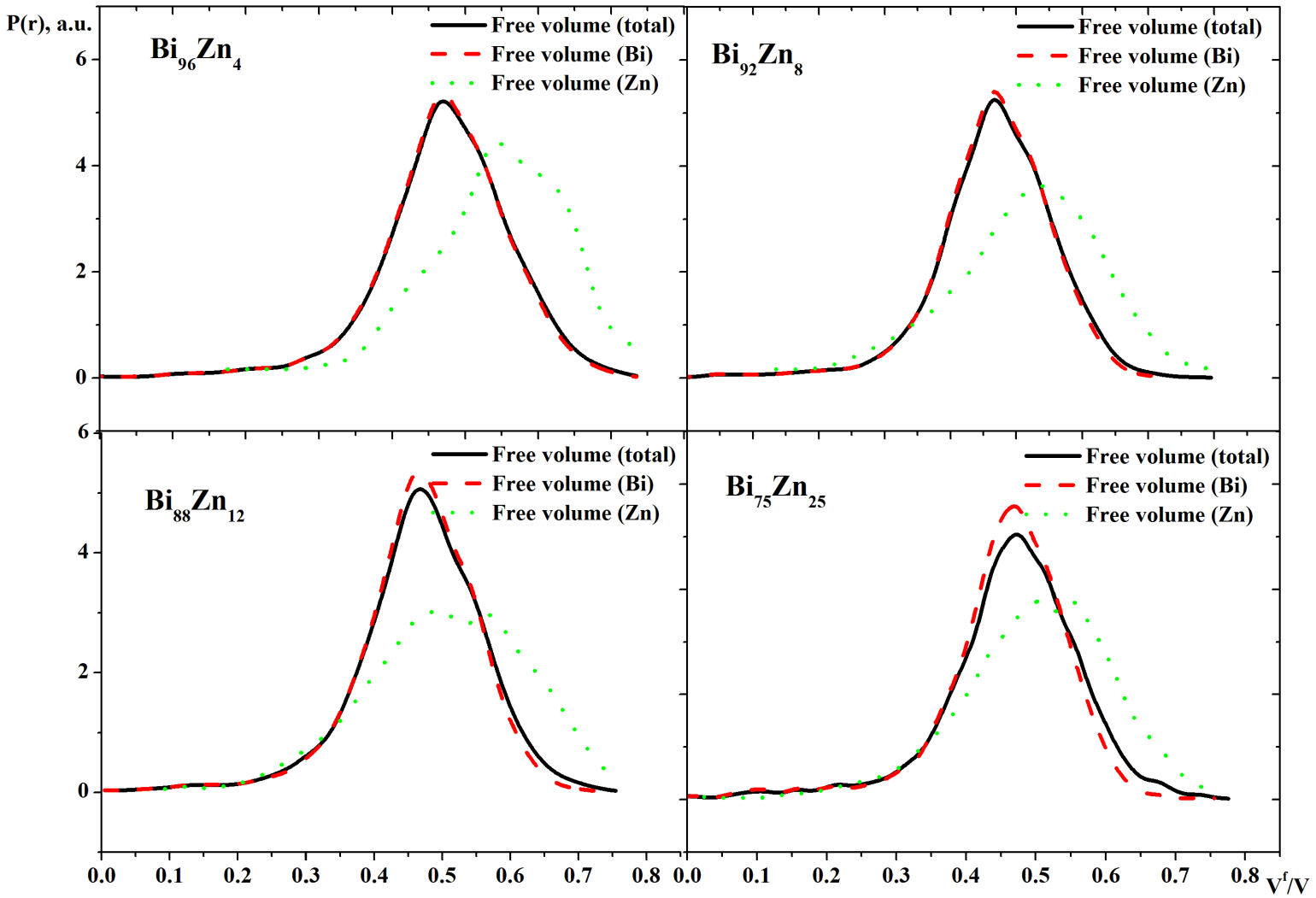

Fig. 11. Differential functions of the relative free volume distribution for some alloys of Bi-Zn system

The analysis of the results obtained both by experimental methods and methods of structure reconstruction makes it possible to explain the mechanism of the formation and transformation of the structure of melts of the $\mathrm{Bi}_{100-x} \mathrm{Zn}_{x}$ system in vicinity of the eutectic concentration. As the concentration dependences of the main structural parameters indicate, the most probable interatomic distances vary little in the range of zinc concentrations from four to six and from 15 to 20 atomic percent. In the near-eutectic region of concentrations, the most probable interatomic distances increase. At the same time, the size of the first coordination sphere at 
a temperature $5 \mathrm{~K}$ above the melting point is almost unchanged, and at higher temperatures even decreases with a zinc content of up to 12 atomic percent. On the other hand, the coordination numbers of melts increase at all temperatures, when zinc content increases.

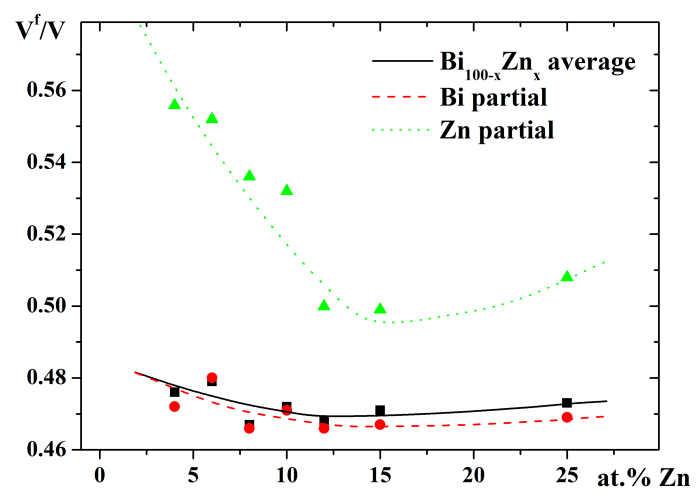

Fig. 12. Concentration dependence of the most probable values of total and partial relative free volume for liquid alloys of the $\mathrm{Bi}_{100-x} \mathrm{Zn}_{x}$ system

As was mentioned earlier, such a change in the main structure parameters within the first coordination sphere may indicate the atomic dissolution of zinc in bismuth when the zinc content is lower than six atomic percent. In the region of near-eutectic concentrations, zinc dissolves in a bismuth based matrix in the form of complexes of two or three atoms. This possibility is indicated by the concentration dependences of the most probable coordination numbers. In this case, the pairs of zinc atoms change the first coordination sphere of the melt so that the first maximum of the pair correlation function becomes asymmetric with a shift of the maximum towards larger interatomic distances without changing the boundary of the first coordination sphere. When the zinc content is higher than 12 percent, longer chains of zinc atoms form, which can not be enclosed by Bi-atoms in the bismuth-based microregions and, therefore, form separate structural units in the intercluster regions.
The transformation of the atomic structure of $\mathrm{Bi}_{100-x} \mathrm{Zn}_{x}$ melts leads to a change in the free volume. Analysis of the results indicates a significant difference between the free volume calculated within the first coordination sphere, which is about 35 percent, and the relative free volume per atom (about 50\%). Such difference in the values of free volume indicates a significant degree of heterogeneity of the studied melts due to their cluster structure, which leads to the formation of two types of atomic ordering. The first type is observed within a cluster with a higher degree of ordering and a smaller fraction of free volume, and the second type of atomic ordering exists in intercluster regions where the degree of atomic ordering is smaller and, accordingly, the free volume is larger.

\section{CONCLUSIONS}

As a result of the structure investigations of $\mathrm{Bi}-\mathrm{Zn}$ near-eutectic alloys, a significant degree of heterogeneity was discovered, which is caused by a large-scale difference in the atomic radii of bismuth and zinc. It was established that the atomic solution of zinc forms in bismuth when the zinc content is lower than six atomic percent. In the region of near-eutectic concentrations, zinc dissolves in a bismuth-based matrix in the form of complexes of two or three atoms. When the zinc content is higher than 12 percent, longer chains of zinc atoms are formed, which can not be enclosed in the bismuthbased clusters and therefore form separate structural units in the intercluster regions. The transformation of the atomic structure of $\mathrm{Bi}_{100-x} \mathrm{Zn}_{x}$ melts leads to a change in the free volume. The essential difference between the values of free volume calculated within the first coordination sphere and the relative free volume per atom indicates a significant degree of heterogeneity of the studied melts due to their cluster structure, which leads to the formation of two types of atomic ordering. Our investigations have also shown that the free volume of zinc atoms changes to a greater extent. This indicates the decisive role of zinc in the formation of the structure of near-eutectic $\mathrm{Bi}_{100-x} \mathrm{Zn}_{x}$ melts.
[1] N. Lazarus, C. D. Meyer, S. S. Bedair, H. Nochetto, I. M. Kierzewski, Smart Mater. Struct. 23, 085036 (2014); https://doi.org/10.1088/0964-1726/23/8/0 85036.

[2] Xuelin Wang, Jing Liu, Micromachines 7, 206 (2016); https://doi.org/10.3390/mi7120206.

[3] T. Daeneke et al., Chem. Soc. Rev. 47, 4073 (2018); ht tps://doi.org/10.1039/C7CS00043J.

[4] T. Massalsky, Binary Alloy Phase Diagrams (Ohio, American Society for Metals: Metalls Park, 1998).

[5] S. Tamaki, S. Takeda, S. Harada, Y. Waseda, E. Matsubara, J. Phys. Soc. Jpn. 55, 4296 (1986); https : //doi.org/10.1143/JPSJ.55.4296.

[6] W. Knoll, P. Lamparter, S. Steeb, Z. Naturforsch. 38a,
395 (1983); https://doi.org/10.1515/zna-1983-0402.

[7] H Ueno et al., J. Phys.: Conf. Ser. 340, 012081 (2012); https: //doi .org/10.1088/1742-6596/340/1/012081.

[8] Md. Riad Kasem, G. M. Bhuiyan, Md. Helal Uddin Maruf, J. Chem. Phys. 143, 034503 (2015); https:// doi.org/10.1063/1.4926573.

[9] Sung S. Kim, T. H. Sanders, Z. Metallkd. 94, 390 (2003); https: //doi .org/10.3139/146.030390.

[10] Y. Djaballah, L Bennour, F. Bouharkat, A. BelgacemBouzida, Modelling Simul. Mater. Sci. Eng. 13, 361 (2005); https://doi.org/10.1088/0965-0393/13/3/0 06.

[11] S. Mudry, Yu. Plevachuk, V. Sklyarchuk, A. Yakymovych, J. Non-Cryst. Solids 354, 4415 (2008); https: 
//doi.org/10.1016/j.jnoncrysol.2008.06.061.

[12] Peng Jia et al., J. Mol. Liq. 214, 70 (2016); https://do i.org/10.1016/j.molliq.2015.12.004.

[13] D. T. Cromer, J. T. Waber, Acta Cryst. 18, 104 (1965); https://doi.org/10.1107/S0365110X6500018X.

[14] S. Mudry, I. Shtablavyi U. Liudkevych, Phys. Chem. Liq. 55, 254 (2017); https://doi.org/10.1080/00319104.2 016.1198482 .

[15] R. L. McGreevy, J. Phys. Condens. Matter. 13, R877 (2001); https://doi.org/10.1088/0953-8984/13 $/ 46 / 201$
[16] R. L. McGreevy, M. A. Howe, Ann. Rev. Mater. Sci. 22, 217 (1992); https://doi.org/10.1146/annurev.ms. 22. 080192.001245.

[17] Y. Waseda, The Structure of Non Crystalline Materials (McGraw-Hill, New York, 1980).

[18] S. I. Mudry, I. M. Shevernoga, Inorg. Mater. 48, 635 (2012); https://doi.org/10.1134/S0020168512060 $12 \mathrm{X}$.

[19] K. Okajima H. Sakao, Transact. Jpn Inst. Metals 23, 111 (1982); https://doi.org/10.2320/matertrans1960 .23 .111

\title{
СТРУКТУРА ТА РОЗПОДІЛ ВІЛЬНОГО ОБ'ЄМУ В РІДКИХ СПЛАВАХ Ві-Zn
}

\author{
I. Штаблавий ${ }^{1}$, В. Плечистий ${ }^{1}$, Б. Ціж ${ }^{2,3}$, С. Мудрий ${ }^{1}$ \\ ${ }^{1}$ Лъвівсъкий націоналъний університет імені Івана Франка, \\ вул. Кирила і Мефоділ, 8, Львів, 79005, Украӥна, \\ ${ }^{2}$ Лввівсъкий націоналъний університет ветеринарной медицини та біотехнологій імені С. З. Гюжицљого, \\ вул. Пекарсъка, 50, Лъвів, 79010, \\ ${ }^{3}$ Університет Казимира Великого, вул. Ходкевича, 30, Бидљощ, 85-064, Полъща
}

Досліджено структуру та розподіл вільного об'єму для біляевтектичних сплавів Bi-Zn з умістом цинку від шести до 25 атомних відсотків за температур на $5 \mathrm{~K}$ вищих від температури плавлення. Для дослідження структури розплавів використано високотемпературний рентгенівський дифрактометр. Щоб запобігти окисленню зразків, експерименти проводили в атмосфері високоочищеного гелію. Геометрія розміщення вхідної шілини рентгенівського променя, центра камери і вхідної щілини лічильника відповідала схемі фокусування типу Брегґа-Брентано. Похибка вимірювання інтенсивності випромінювання була в межах $2 \ldots 3 \%$. Температуру вимірювали та підтримували 3 точністю $\pm 2 \mathrm{~K}$. Реконструювали атомну структуру оберненим методом Монте-Карло. Для цього створено кубічну комірку, що містила 5000 атомів. Розміри модельної комірки вибирали відповідно до густини розплаву при температурі, за якої проводили експеримент.

Виявлено значний ступінь гетерогенності розплавів, що спричинено значною різницею в атомних радіусах вісмуту та цинку. Встановлено утворення атомарного розчину цинку у вісмуті, коли вміст цинку менше шести атомних відсотків. У зоні біляевтектичних концентрацій цинк розчиняється в матриці на основі вісмуту у вигляді комплексів двох-трьох атомів. Коли вміст цинку становить більше 12 відсотків, утворюються довші ланцюги атомів цинку, які не можуть міститися в кластерах на основі вісмуту i, отже, утворюють окремі структурні одиниці в міжкластерних зонах.

Реконструкція атомної структури дала змогу отримати значення парціальних координаційних чисел та обчислити величину загального й парціального вільного об'єму. В результаті досліджень установлено також значну різницю між розміром вільного об'єму в межах першої координаційної сфери та його середніми значеннями. Передбачається, що основна причина цих відмінностей зумовлена особливостями механізму розчинення цинку у вісмуті за його низьких концентрацій та утворенням ланцюгів атомів цинку в матриці вісмуту за вищого вмісту цинку в розплавах.

Ключові слова: рідкі сплави, структура ближнього порядку, структурна модель, вільний об'єм. 